\title{
Proposed Plan/Statement of Basis for the Grace Road Site (631-22G) Operable Unit: Final Action
}

by

E. Palmer

Westinghouse Savannah River Company

Savannah River Site

Aiken, South Carolina 29808

\section{RECEIVED \\ JAN 151998 \\ OSTI}

\section{MASTER}

DOE Contract No. DE-AC09-89SR18035

This paper was prepared in connection with work done under the above contract number with the U.S. Department of Energy. By acceptance of this paper, the publisher and/or recipient acknowledges the U. S. Government's right to retain a nonexclusive, royalty-free license in and to any copyright covering this paper, along with the right to reproduce and to authorize others to reproduce all or part of the copyrighted paper. 


\section{United States Department of Energy}

Savannah River Site

\section{Statement of Basis/Proposed Plan for the \\ Grace Road Site (BIdg. \#631 -22G) \\ Operable Unit : Final Action (U)}

WSRC-RP-96-105

Revision 1

July 17, 1996

Westinghouse Savannah River Company

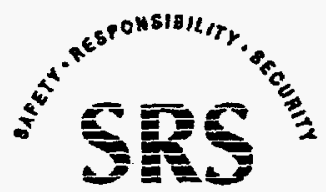

SAYANMAH RIVER SITE

Savannah River Site

Aiken, South Carolina 29808

Prepared for the U.S. Department of Energy Under Contract DE-AC89-SR18035 


\section{CERTIFICATION}

\section{Statement of Basis/Proposed Plan for the Grace Road Site (631-22G) \\ Revisional, WSRC-RP-96-105

"I certify under the penalty of law that this document and all attachments were prepared under my direction or supervision in accordance with a system designed to assure that qualified personnel properly gather and evaluate the information submitted. Based on my inquiry of the person or persons who manage the system, the information submitted is, to the best of my knowledge and belief, true, accurate, and complete. I am aware that there are significant penalties for submitting fake information, including the possibility of fines and imprisonment for knowing violations."

Date:

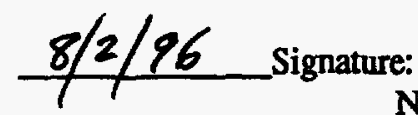

Name:

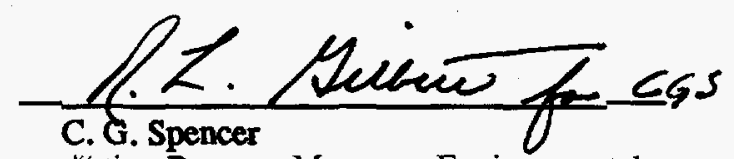

Title:"

Acting Program Manager, Environmental

Restoration

Westinghouse Savannah River company

Contractor for the U.S. Dept. of Energy

Savannah River Operations

Date:

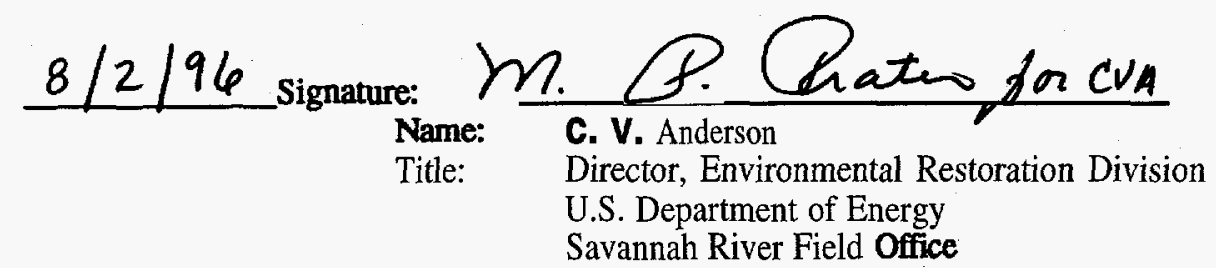




\section{DISCLAIMER}

This report was prepared as an account of work sponsored by an agency of the United States Government. Neither the United States Government nor any agency thereof, nor any of their employees, makes any warranty, express or implied, or assumes any legal liability or responsibility for the accuracy, completeness, or usefulness of any information, apparatus, product, or process disclosed, or represents that its use would not infringe privately owned rights. Reference herein to any specific commercial product, process, or service by trade name, trademark, manufacturer, or otherwise does not necessarily constitute or imply its endorsement, recommendation, or favoring by the United States Government or any agency thereof. The views and opinions of authors expressed herein do not necessarily state or reflect those of the United States Government or any agency thereof.

This report has been reproduced directly from the best available copy.

Available to DOE and DOE contractors from the Office of Scientific and Technical Information, P.O. Box 62, Oak Ridge, TN 37831; prices available from (615) 576-8401.

Available to the public from the National Technical Information Service, U.S. Department of Commerce; 5285 Port Royal Road, Springfield, VA 22161. 


\section{DISCLAIMER}

Portions of this document may be illegible electronic image products. Images are produced from the best available original document. 
Table of Contents

Page

Executive Summary Es-1

$\begin{array}{llr}\text { SECTION I } & \text { Introduction and Background } & 1 \\ \text { SECTION II } & \text { Community Involvement } & 2 \\ \text { SECTION III } & \text { Scope and Role of Operable Unit or Response Action } & 4 \\ \text { SECTION IV } & \text { Media Specific Operable Unit - Grace Road Site } & 4 \\ \text { SECTION IV.A } & \text { Unit Description and History } & 4 \\ \text { SECTION IV.B } & \text { Operable Unit Risks } & 7 \\ \text { SECTION IV.C } & \text { Summary of Considered Altematives } & 10 \\ \text { SECTION IV.D } & \text { Summary of the No Action Alternative } & 10 \\ \text { REFERENCES } & & 11 \\ \text { GLOSSARY } & & 12\end{array}$

List of Figures

Page

Figure 1. Location of Grace Road Site in Relation to Major SRS Facilities

Figure 2. General Configuration of the Grace Road Site

List of Tables

Table 1. Comparison of Unit Specific Soil Concentration to Two (2) Times Background

Table 2 Carcinogenic/Non-Carcinogenic Results for Arsenic. 


\section{List of Acronyms}

$\begin{array}{ll}\text { ARARS } & \text { Applicable or Relevant and Appropriate Requirements } \\ \text { bgs } & \text { below ground surface } \\ \text { BRA } & \text { Baseline Risk Assessment } \\ \text { CERCLA } & \text { Comprehensive Environmental Response, Compensation, and Liability - } \\ & \text { Act } \\ \text { CMS/FS } & \text { Corrective Measures Study/Feasibility Study } \\ \text { COPC } & \text { contaminant of potential concern } \\ \text { DOE } & \text { U.S. Department of Energy } \\ \text { DOT } & \text { U.S. Department of Transportation } \\ \text { EPA } & \text { U.S. Environmental Protection Agency } \\ \text { FFA } & \text { Federal Facility Agreement } \\ \text { GPR } & \text { ground penetrating radar } \\ \text { GRS } & \text { Grace Road Site waste unit } \\ \text { HI } & \text { Hazard Index } \\ \text { HQ } & \text { Hazard Quotient } \\ \text { mSl } & \text { mean sea level } \\ \text { NCP } & \text { National Oil and Hazardous Substance Pollution Contingency Plan } \\ \text { NPL } & \text { National Priorities List } \\ \text { OSWER } & \text { Office of Solid Waste and Environmental Restoration (USEPA) } \\ \text { PIP } & \text { Public Involvement Plan } \\ \text { RBC(s) } & \text { risk based contaminant(s) } \\ \text { RCRA } & \text { Resource Recovery and Conservation Act } \\ \text { RfD } & \text { reference dose } \\ \text { RFI } & \text { RCRA Facility Investigation } \\ \text { RI } & \text { Remedial Investigation } \\ \text { ROD } & \text { Record of Decision } \\ \text { SARA } & \text { Superfund Amendments and Reauthorization Act } \\ \text { SCDHEC } & \text { South Carolina Department of Health and Environmental Control } \\ \text { SRS } & \text { Savannah River Site } \\ \text { T\&E } & \text { Threatened and Endangered } \\ \text { WSRC } & \text { Westinghouse Savannah River Company } \\ & \end{array}$




\section{EXECUTIVE SUMMARY}

This Statement of Basis/Proposed Plan is being issued by the U.S. Department of Energy (DOE), which functions as the lead agency for the Savannah River Site (SRS) remedial activities, with concurrence by the U.S. Environmental Protection Agency, and the South Carolina Department of Health and Environmental Control (SCDHEC).

The purpose of this Statement of Basis/Proposed Plan is to describe the preferred alternative for addressing the Grace Road Site (GRS) located at the SRS, in Aiken, South Carolina and to provide an opportunity for public input into the remedial action selection process. R.61-79.124 of the South Carolina Hazardous Waste Management Regulations (SCHWMR) and Section 117(a) of the Comprehensive Environmental Response, Compensation, and Liability Act (CERCLA), as amended, require advertisement of a draft RCRA permit modification and notice of proposed remedial actions (i.e., the Statement of Basis/Proposed Plan).

The results of the Resource Conservation and Recovery Act (RCRA) Facility Investigation / Comprehensive Environmental Response Compensation and Liability Act (CERCLA) Remedial Investigation $(\mathrm{Ml} / \mathrm{RI})$, indicate that there is no impact to human health or the environment from the Grace Road Site. Therefore, the DOE, EPA - Region IV, and SCDHEC are proposing that no action is needed at the unit. No other alternatives were considered. This is a proposed final action for the Grace Road Site.

The Grace Road Site is located 1.3 kilometers $(0.8$ miles) south of B-Area and east of the intersection of Grace Road with SRS Road 2. The unit is roughly rectangular in shape and has a northwest-southeast orientation. Approximate dimensions of the unit are 396.3 meters ( 1,300 feet) by 97.6 meters ( 320 feet) and it covers an area of about 3.8 hectares ( 9.6 acres). Waste at the unit consisted of drums and cans in a variety of sizes ranging from less than 1 gallon to 55 gallon drums, car seat springs, car and truck parts, old foundations, bricks, shingles, and slabs of concrete. The Grace Road area was originally a tenant-operated farm which later seined as the laydown yard for the construction of B-Area,

AU the debris, drums and concrete slabs were removed from the area in 1992. The area was then graded and seeded.
No documentation was found indicating that the GRS was ever used for hazardous or non-hazardous waste disposal activities. There is no evidence of any recent disposal activity nor that the disposal activity was more widespread.

The only contaminant of potential concern (COPC) identified in the risk assessment that exceeded a risk of $1 \times 10^{-6}$ was arsenic and it is less than $3.8 \times 10^{-5}$, which is within the EPA target risk range of one in ten thousand $\left(10^{-4}\right)$ to one in one million (10-6). Arsenic detected in the unit specific samples had a maximum concentration of $3.2 \mathrm{mg} / \mathrm{kg}$. It should also be noted that arsenic was a component of agricultural chemicals in the period before SRS existed Since the Grace Road area was a farm prior to SRS, it is likely that the detected values may be a result of pre1950 farming activities. SRS unimpacted area values for arsenic range from less than $0.5 \mathrm{mg} / \mathrm{kg}$ to $15.2 \mathrm{mg} / \mathrm{kg}$.

Since the arsenic detected is not from the unit, the source of the arsenic will be evaluated on a site-wide scale during the Soil Background Study (or possibly as part of a Site-wide Soil Integrator Operable Unit).

Based on the investigation performed at the Grace Road Site, it is recommended that no remedial action be performed at this unit.

Community involvement in the remedial action selection process for the GRS is strongly encouraged. All submitted comments will be reviewed and considered. A Responsiveness Summary to address significant issues raised during the public comment period will be made available in the final RCRA permit modification and the Record of Decision (ROD). The final remedial decision for the unit will be documented in the final RCRA permit modification decision and the Record of Decision. 


\section{SECTION I: INTRODUCTION AND BACKGROUND}

\section{Introduction}

This Statement of Basis/Proposed Plan is issued by the U.S. Department of Energy, which functions as the lead agency for SRS remedial activities, and with concurrence by the EPA, and the SCDHEC. The purpose of this Statement of Basis/Proposed Plan is to describe the preferred alternative for addressing the Grace Road Site (BIdg. \# 631-22G) located at SRS, in Aiken, South Carolina.

The results of the Resource Conservation and Recovery Act (RCRA) Facility Investigation/Comprehensive Environmental Response Compensation and Liability Act (CERCLA) Remedial Investigation (RFI/RI), indicate that the GRS poses no risk to human health or the environment. Therefore, the DOE, EPA - Region IV, and SCDHEC are proposing that no action is needed at the unit. No other remedial alternatives were considered This is a proposed final action for the waste unit.

SRS manages certain waste materials which are regulated under RCRA, a comprehensive law, requiring responsible management of hazardous waste. RCRA 3004(u) requires that releases from solid waste management units be investigated and remediated as necessary. The Grace Road Site is a solid waste management unit regulated under RCRA 3004(u).

SRS has a RCRA hazardous waste permit from SCDHEC that mandates that SRS establish and implement an RFI Program to fulfill the requirements specified in RCRA Section 3004(u). On December 21, 1989, SRS was included on the National Priorities List (NPL). This inclusion created a need to integrate the established RFI Program with CERCLA requirements to provide for a focused environmental program. In accordance with Section 120 of CERCLA, DOE has negotiated a Federal Facility Agreement (FFA, 1993) with EPA - Region IV and SCDHEC to coordinate remedial activities at SRS into one comprehensive strategy which fulfills these dual regulatory requirements.

Both RCRA and CERCLA require that the public be given the opportunity to review and comment on the draft permit modification and the proposed remedial alternative. Public participation requirements are listed in SCHWMR R.61-79.124 and Sections 113 and 117 of CERCLA. These requirements include the establishment of an Administrative Record File that documents the selection of remedial alternatives and allows for review and comment by the public regarding those alternatives. The Administrative Record File must be established "at or near the facility of issue." The SRS Public Involvement Plan (DOE, 1994) is designed to facilitate public involvement in the decision-making process for permitting, closure, and the selection of remedial alternatives. SCHWMR R.61-79. 124 and Section 117(a) of CERCLA, 1980, as amended, require advertisement of the draft permit modification and proposed remedial action and provide the public an opportunity to participate in the selection of the remedial action.

This Statement of Basis/Proposed Plan is a summary of the Administrative Record File leading to the selection of the preferred alternative. The Statement of Basis/Proposed Plan presents the preferred alternative and the rationale for selecting the alternative. Public participation in considering this proposed action is strongly encouraged

SCHWMR R.61-79. 124 requires that a brief description and response to all significant comments be made available to the public as part of the RCRA Administrative Record. Following the public comment period, a Responsiveness Summary will be prepared to address significant issues raised during the public comment period. The Responsiveness Summary will be made available with the final RCRA permit modification and in the ROD. All

- submitted comments will be reviewed and considered

Following the public comment period and after all comments have been reviewed and considered, DOE, in consultation with EPA - Region IV and SCDHEC, will select the final remedial action, that will satisfy the FFA requirements. The final selection of the remedial alternative under RCRA will be in the form of a final permit modification decision which will be made by SCDHEC. It is important to note that the final action may differ from the preferred alternative discussed in this plan, depending upon the public participation. The final alternative chosen will be protective of human health and the environment and comply with all Federal and State environmental laws.

In order to gain a better understanding of CERCLA activities as they pertain to the unit, the public is encouraged to review the Administrative Record File for this unit. Refer to Section II of this document for information regarding availability and access to the Administrative Record File.

\section{Background}

SRS occupies approximately 310 square miles of land adjacent to the Savannah River, principally in Aiken 
and Barnwell Counties of South Carolina (Figure 1). SRS is a secured U.S. government facility with no permanent residents. The Site is located approximately 25 miles southeast of Augusta, Georgia, and 20 miles south of Aiken, South Carolina.

SRS is owned by DOE. Management and operating services are provided by Westinghouse Savannah River Company (WSRC). SRS has historically produced tritium, plutonium, and other special nuclear materials for national defense. SRS has also provided nuclear materials for the space program and for medical, industrial, and research efforts.

The FFA lists the Grace Road Site (Bldg. \#63 1-22G) as a RCRA/CERCLA unit requiring further evaluation to determine the actual or potential impact to human health and the environment.

\section{SECTION II: COMMUNITY INVOLVEMENT}

This document summarizes information that is provided in greater detail in the Administrative Record File, which is available for review by the public at the following locations:

\section{U.S. Department of Energy}

Public Reading Room

Gregg-Graniteville Library

University of South Carolina-Aiken

171 University Parkway

Aiken, South Carolina 29801

(803) 641-3465

Thomas Cooper Library

Government Documents Department

University of South Carolina

Columbia, South Carolina 29208

(803) $777-4866$

Similar information is available through the repositories listed below:

Reese Library

Augusta State University

2500 Walton Way

Augusta, Georgia 30910

(706) $737-1744$

Asa H. Gordon Library

Savannah State University

Tompkins Road

Savannah, Georgia 31404

(912) $356-2183$
The RCRA Administrative Record File for SCDHEC is available for review, by the public, at the following locations:

The South Carolina Department of Health and Environmental Control

Bureau of Solid and Hazardous Waste Management

8901 Farrow Road

Columbia, SC 29203

(803) 896-4000

Lower Savannah District

Environmental Quality Control Office

215 Beaufort St., N. E.

Aiken, South Carolina 29802

(803) 648-9561

The public will be notified of a public comment period through mailing of the SRS Environmental Bulletin, a newsletter sent to approximately 3500 citizens in South Carolina and Georgia, and through notices in the Aiken Standard, the Allendale Citizen Leader, the Barnwell People-Sentinel, The State, and the Augusta Chronicle newspapers. The public comment period will also be announced on local radio stations.

DOE will provide the opportunity for a public meeting during the public comment period if significant interest is expressed. The public will be notified of the date, time, and location. At the meeting, the proposed action will be discussed and questions about the action will be answered. Written and oral comments will be accepted and considered prior to a final decision.

To request a public meeting during the comment period, submit written comments about this proposed action, or to obtain more information concerning this Statement of Basis/Proposed Plan, contact one of the following

Mary Flora

Public Involvement

Westinghouse Savannah River Company

730-2B, 128

Aiken, South Carolina 29803

(803)952-6852 


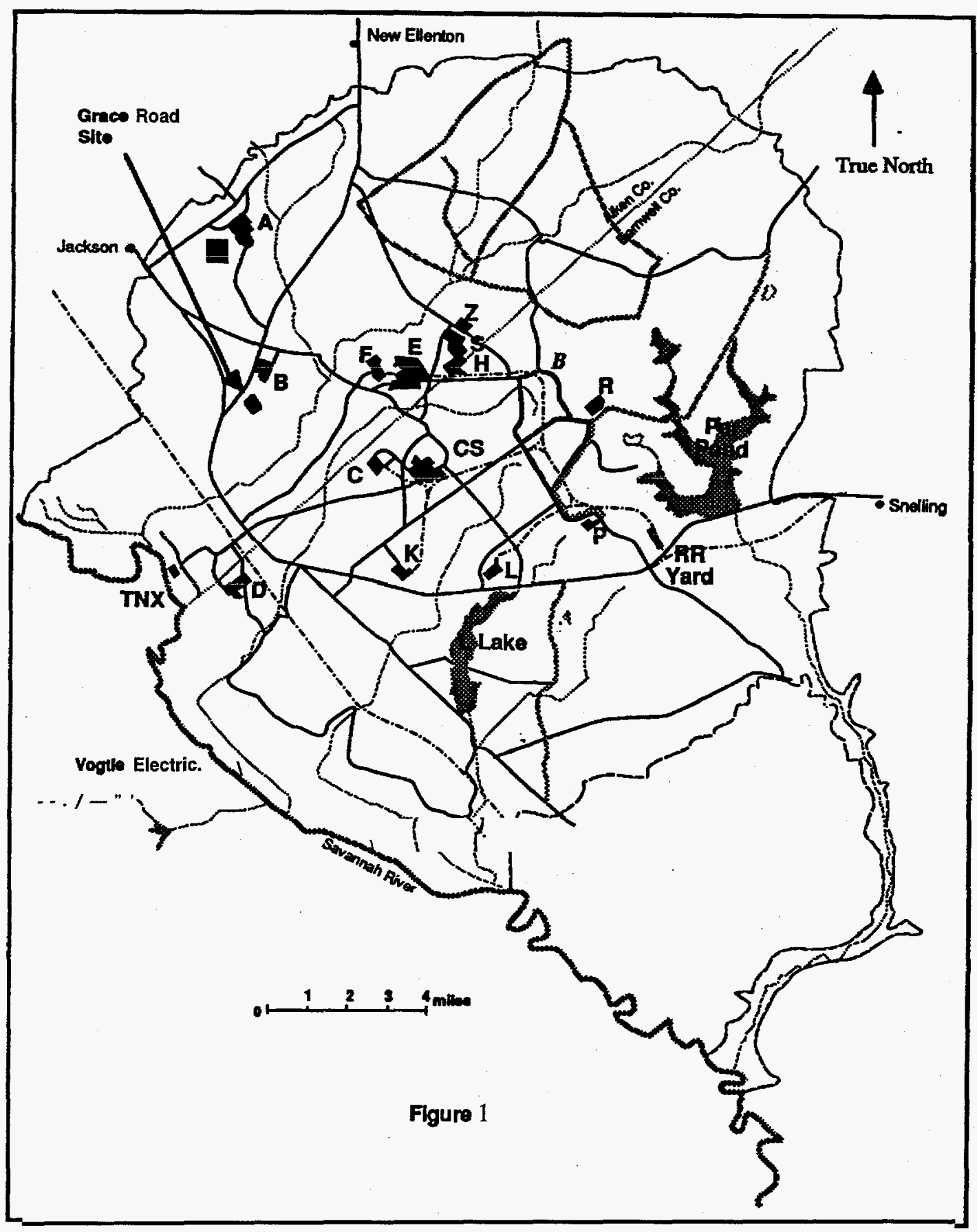

Figure 1. Location of the Grace Road Site at the Savannah River Site. 
The South Carolina Department of Health and Environmental Control

Attn: G. Randall Thompson, P.E., Director

Division of Hazardous and Infectious Waste

Bureau of Solid and Hazardous Waste Management

8901 Farrow Road

Columbia, South Carolina 29203

(803) $896-4000$

DOE, EPA-Region IV, and SCDHEC strongly encourage community participation in the remedial action selection process for the GRS. A Responsiveness Summary to address issues raised by the public will be made available following the public comment period, if any comments are received, and with the Record of Decision and RCRA permit.

Following the public comment period and a review and consideration of all submitted comments, ROD will be signed and a final decision for the RCRA permit will be issued The alternative chosen must be protective of human health and the environment and comply with all Federal and state environmental laws.

\section{SECTION III: SCOPE AND ROLE OF OPERABLE UNIT OR RESPONSE ACTION WITHIN THE SITE STRATEGY}

The overall strategy for addressing the Grace Road Site operable unit was to: 1) determine if there had been a release of hazardous substances; 2) determine the nature and extent of any contamination; 3 ) perform a baseline risk assessment; and 4) evaluate the need for remedial action to address any potential risk to human health and the environment.

The investigation and risk assessment have been completed for the GRS. Since the results of the investigation indicate that there is no impact to human health or the environment, no action is being recommended by this proposed plan. Arsenic was the only substance identified as a contaminantt of potential concern by the risk assessment. The values detected were above unit specific background levels. However, the arsenic did not appear to be from the Grace Road Site. It is possible that the arsenic is from farming activities prior to SRS being built.

The GRS is part of the larger Upper Three Runs watershed consisting of several surface and groundwater units. It has been determined that GRS does not contribute contaminati' on to the area groundwater within the watershed. The source of the arsenic will be evaluated on a Site-wide scale during the implementation of the Soil Background Study (or possibly in a Site-wide Soil Integrator Operable Unit Work Plan). The proposed action for GRS is a final action.

\section{SECTION IV: MEDIA SPECIFIC OPERABLE UNIT - GRACE ROAD SITE}

\author{
Section IV.A Unit Description, History, and \\ Media to be Addressed
}

\section{Unit Description and Location -}

GRS is located approximately 1.3 kilometers $(0.8 \mathrm{mi})$ south of B-Area and about 244 meters ( 800 yards) east of the intersection of Grace Road and SRS Road 2. The unit is roughly rectangular in shape and has a northwest-southeast orientation running parallel to Grace Road. The unit is approximately 396.3 meters $(1300 \mathrm{ft})$ by 97.6 meters $(320 \mathrm{ft})$. It covers an area of about 3.8 hectares ( 9.6 acres), see Figure 2.

Prior to the establishment of SRS, Grace Road Site was part of a tenant-operated farm owned by Mrs. Elise Grace. The farm consisted of about 217.6 hectares (S44 acres) of which 92 hectares (230 acres) were under cultivation, and the remaining 125.6 hectares (314 acres) were in woodlands and swamp lands. Transfer records of this land to the U. S. Government in January 1951 indicate that this land had been a farm (part of the Red Hill Plantation) since the late 1890's.

Buildings on the farm consisted of a main house, dog kennel, machine shed, oil house, two cottages, two turkey houses, two barns, garage, cook house, twostory barn, water tower with meat house, storage shed, grain storehouse, hay storage barn and an outhouse (privy). The majority of the buildings had a foundation of bricks, concrete or tile blocks. Several buildings, including the dog kennels and turkey houses, had concrete slab floors. The water tower also had massive concrete blocks that were used to hold treated timber stanchions that supported the water tank. Photographs of the farm show at least two gasoline powered tractors in the machine shed, a truck and other assorted farm machinery.

After purchase by the Government, the area in and around the farm was utilized as a laydown yard for materials used in the construction of the B-Area. The length of time that it was utilized for this purpose is unknown, but is estimated to be two to three years. There are no records to indicate that this unit has been used for any other purpose since it was closed as a laydown yard in the mid-1950s.

The Grace Road Site consisted of numerous concrete slabs, brick foundations (pre-SRS) and miscellaneous debris. Small mounds of concrete, bricks, shingles, car and truck parts and large concrete blocks that appear to be pieces of a bridge were placed at the unit. The unit also contains numerous drums and cans varying in size 
from 1/'2 gallon cans to 55 gallon drums and various car parts. A few of the smaller cans and drums are labeled oil and grease. Most of the debris was on the surface or partially buried in scattered locations across the unit.

The nearest surface water is the Upper Three Runs Creek which is approximately $2.4 \mathrm{~km}(1.5 \mathrm{mi})$ east of the unit and an unnamed branch $1.6 \mathrm{~km}(1 \mathrm{mi})$ to the west. Most of the unit is covered in tall grasses and weeds with some scattered trees and low shrubs.

Numerous wells are located in the vicinity of Grace Road. None of the wells are specifically in place to monitor the Grace Road Site. One well cluster is located about 30 feet northeast of the unit and another is 40 feet southeast of the unit. Water table elevations in these wells indicate that the water table is above 200 feet mean sea level or approximately 80 feet below ground surface. The unit appears to be in the middle of a recharge zone and groundwater flows south and east from it.

The upper soil layers at the unit consist mainly of fine to medium grained sands mixed with small amounts of silt and clay containing traces of lignite. Clay content in the soils increases with depth. From a depth of approximately 10 feet downward to the lowest sampling depth of 20 feet, the sediment is a hard compact red clay.

All the drums, cans and jars located at the unit were free of any hazardous waste material

Soil sample locations were chosen near the areas where the drums and cans were concentrated This was done to determine the extent of any contamination released to the soils from the drums.

No records of any type of waste management activity have been found for the Grace Road Site. Based upon available information, i.e., literature search and records search, no hazardous materials have been managed or disposed of at Grace Road. In 1992, all debris at the GRS was removed from the area and either sent to the sanitary landfill or used for erosion control (concrete bids).

\section{History of Unit / Conceptual Release Model}

There is no documented information available regarding past hazardous or non-hazardous waste disposal activities at GRS. Markings on the drums found at the unit suggest that they once contained oil and grease. There is no evidence that any recent disposal activity has occurred or that the disposal activity was more widespread. Also, there is no evidence of any burning or excavation at this waste unit.
Between February and May 1992, all the debris, drums and concrete slabs were removed from the Grace Road Site. The items removed were either used at soil erosion control areas or disposed of in the sanitary landfill. The EPA and SCDHEC granted approval prior to SRS removing the materials from the waste unit.

Only surface disposal activities appear to have occurred at the GRS. Based on this, the conceptual release model consisted of a release to surface soils with a potential for leaching to subsurface soils, and only surface and subsurface soils were investigated. For a detailed explanation of the release model, potential receptors and the fate and transport of contamination, see the RFI/RI report for the Grace Road Site (63 122G), WSRC-RP-95-93 (WSRC, 1996).

\section{Media Assessment}

Soil/vadose zone and groundwater investigations were conducted between 1990 and 1994. The initial investigation was based on a 1988 soil gas survey which detected low levels of hydrocarbons and chlorinated hydrocarbons. Detailed descriptions of the investigation and characterization conducted at the Grace Road Site may be found in the RCRA Facility Investigation/Remedial Investigation Report for the Grace Road Site (63I -22G), WSRC-RP-95-93 (WSRC, 1996) and the RCRA Facility Investigation /Remedial Investigation Plan for the Grace Road Site, WSRC-RP.$\$ 01250$ (WSRC, 1990).

\section{Groundwater}

Groundwater samples from wells near the Grace Road Site indicate that there is no groundwater contamination.

\section{Surface Water/Sediment}

No surface water or sediment sampling was conducted because the nearest surface water feature is located over 1 mile from the GRS.

\section{Soils}

The soils investigation was designed to assess the horizontal extent and vertical migration of any hazardous constituents at the unit and to evaluate (prove/disprove) the release model.

The soils investigation included taking soil samples (1990 and 1994), an electromagnetic survey (1990), a ground penetrating radar (GPR) survey (1994) and a soil gas survey (1994). 


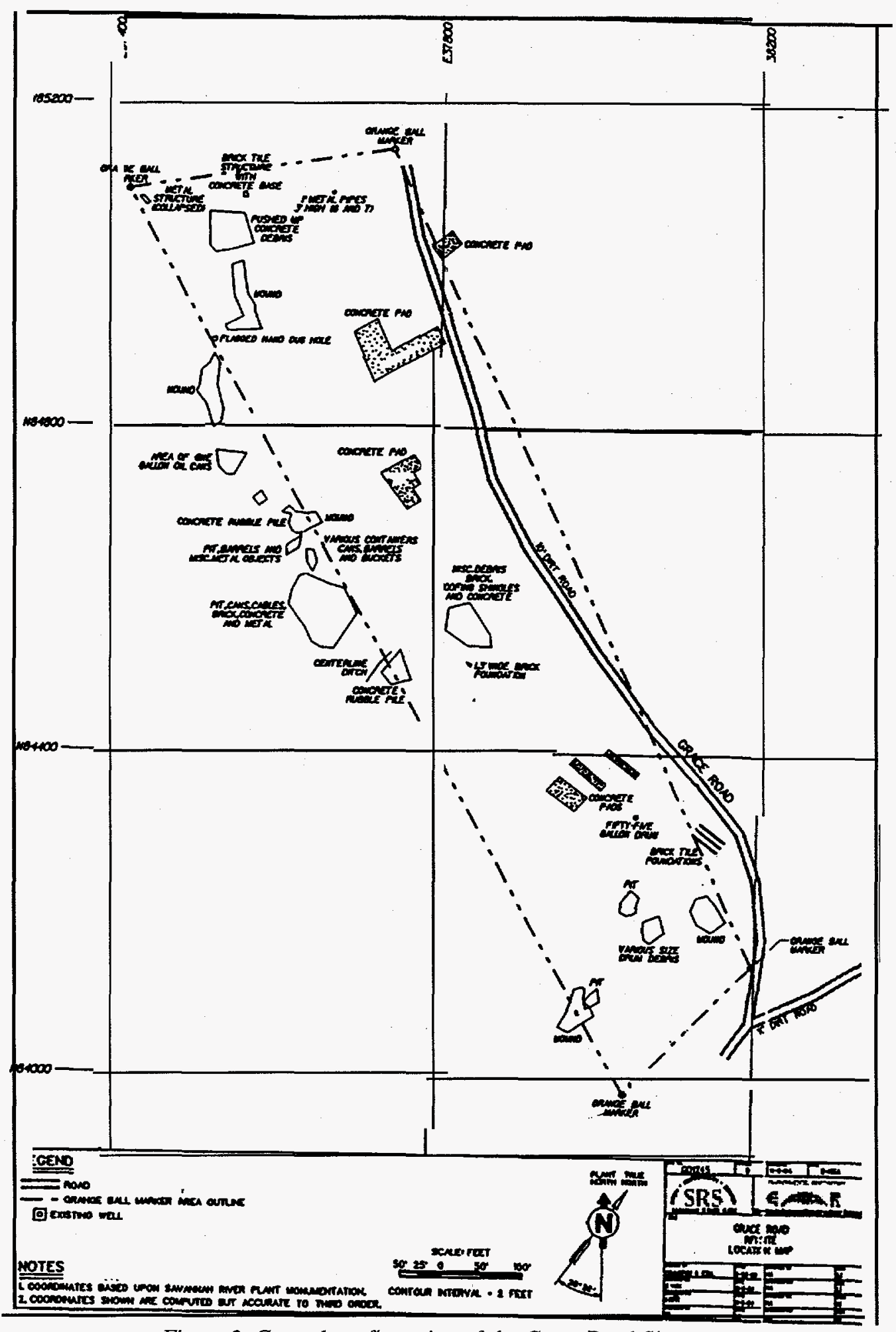

Figure 2. General configuration of the Grace Road Site. 
The magnetometer survey and the GPR survey indicated that there are no buried materials at the unit.

An extensive soil gas survey was performed in 1994. A total of 85 sample locations were established and samples collected at each location. Species monitored for this survey were: light hydrocarbons $\left(C_{1}-C_{4}\right)$; gasoline range normal paraffins $\left(\mathrm{C}_{5}-\mathrm{C}_{\mathbf{1 0}}\right)$; gasoline range aromatic hydrocarbons, (BTEX); diesel range hydrocarbons $\left(\mathrm{C}_{11}-\mathrm{C}_{17}\right)$; selected organics; and mercury.

The levels of volatiles and diesel range organics observed in the survey were very low with most below minimum detection levels. Levels of light hydrocarbons and mercury were indicative of background concentration in the SRS area. No evidence of contamination was detected at this unit by the soil gas survey.

Confirmation soil sampling served as a screening for semi-volatile and volatile organic compounds, metals, and radionuclides. In addition, Appendix IX parameters were also analyzed Results from the soil gas survey conducted in 1988 and the location of the debris/rubble were used to select soil sample locations. Background samples were also obtained for comparison purposes.

Metals found in concentrations greater than analytical method detection limits were arsenic, barium, cadmium, chromium, mercury, lead, selenium, tin, vanadium and zinc. Acetone, methylene chloride and bis(2ethylhexyl)phthalate were also detected. Phthalate species are used as plasticizers for cellulose, glass, plastic, and rubber products. Other substances detected, such as acetone, xylene, and methylene chloride are commonly used as laboratory solvents. Radionuclide indicator parameters (gross alpha, non-volatile beta) were within background. See Table 1 for constituent concentrations and background levels.

The concentration levels of the analytes, with the exception of arsenic and lead, were within background levels and were insignificant in terms of having an effect on human health and the environment. The concentration levels detected at the unit for arsenic ranged from 2.6 to $3.2 \mathrm{mg} / \mathrm{kg}$ and for lead ranged from 0.9 to $48.1 \mathrm{mg} / \mathrm{kg}$.

\section{Section IV.B Operable Unit Risks}

\section{Human Health Risks}

As part of the RCRA/CERCLA process for the Grace Road Site, a risk assessment was performed using the data generated during the assessment phase. Detailed information regarding the development of COPCs, the fate and transport of contaminants and the risk assessment can be found in the RFIIRI Report for Grace Road Site (631 -22 G), WSRC-RP-95-93 (WSRC, 1996).

After combining analytical data and eliminating those analytes not detected in any samples, the data were evaluated on the basis of quality with respect to sample quantitation limits, frequency of detection, relative toxic potential of the constituent, laboratory qualifiers and codes, and blanks. The remaining data (constituents detected) were compared to 2 times the unit specific background and EPA developed Risk Based Concentrations (RBCs).

RBCS developed by EPA Region III (EPA, 1995) were used to screen the chemicals of potential concern for the Grace Road Site. This guidance provides reference doses and carcinogenic potency data for nearly 600 chemicals. These toxicity constants have been combined with "standard" exposure scenarios to calculate RBCS chemical concentrations corresponding to fixed levels of *(i. e., a hazard quotient of 1 , or a lifetime cancer risk of one in one million. The RBCS are very similar to preliminary remediation goals which are concentration goals for individual chemicals for a specific medium and land use combinations at CERCLA units.

As a result of comparing the unit sample concentrations to 2 times the background concentrations and EPA-III RBC values (Table 1), only two chemicals remain to be studied further, arsenic and lead.

The screening level for lead in soil is $400 \mathrm{mg} / \mathrm{kg}$ for residential land use. This value is described in OSWER Directive 9355.4-12, Revised Internal Soil Lead Guidance for CERCLA Sites and RCRA Corrective Action Facilities, dated July 14,1994 and issued by the USEPA (EPA, 1994). Because the lead concentrations ranged from 0.9 to $48.1 \mathrm{mg} / \mathrm{kg}$, which were far below the EPA guidance level, lead was eliminated as a COPC.

Since arsenic was not eliminated from the screening process, calculations were performed to determine the risk for the on-unit resident scenario. Note however, that arsenic was used as a component of agricultural chemicals in the period before SRS existed and that Grace Road was a farm. Thus, a few of the detected values may be a result of farming activities prior to 1950. SRS site wide values for arsenic range from less than $0.5 \mathrm{mg} / \mathrm{kg}$ to $15.2 \mathrm{mg} / \mathrm{kg}$. The SRS maximum concentration level for arsenic in Blanton (the soils type found at Grace Road) soils is $7.05 \mathrm{mg} / \mathrm{kg}$.

A complete exposure pathway consists of the following four elements: (1) a source and mechanism of contaminant release to the environment, (2) an environmental transport medium for the released 
contaminants, (3) a point of contact with the contaminated medium, and (4) a route of entry of the contaminant into the receptor at the exposure point. If any of these elements were missing, the pathway was incomplete and was not considered in the baseline risk assessment (BRA) for Grace Road. Only one land use scenario was considered future land use (residential). The potential human receptor addressed was a hypothetical future on-unit resident. A current on-unit worker scenario was not performed because no worker activity is conducted in the area.

Cancer risks are estimated as the incremental probability of an individual developing cancer over a lifetime as a result of pathway-specific exposure to carcinogenic contaminants. The risk to an individual resulting from exposure to non-radioactive chemical carcinogens is expressed as the increased probability of a cancer occurring over the course of a 70 year lifetime. Cancer risks are related to the EPA target range of one in ten thousand $\left(1 \times 10^{-04}\right)$ to one in one million $\left(1.0 \times 10^{-}\right.$ 06 ) for incremental cancer risk at NPL sites. Risk levels at or above $1 \times 10^{-04}$ are considered significant and generally warrant remediation. In order to account for simultaneous exposure to multiple carcinogens through a given pathway, the risks calculated for each individual carcinogen in that medium were summed to obtain an estimate of the total cancer risk for the pathway.

Non-carcinogenic effects are evaluated by comparing an exposure level over a specified time period (e.g., lifetime) with a reference dose (RfD) derived for a similar exposure period. To evaluate the noncarcinogenic effects of exposure to soil contaminants, the hazard quotient, HQ (the ratio of the exposure dose to the RfD) is calculated for each contaminant. The non-carcinogenic HQ assumes that below a given level of exposure (i.e., the RfD), even sensitive populations are unlikely to experience adverse health effects. If the exposure level exceeds this threshold there may be concern for potential non-carcinogenic health effects.

HQs are summed for each exposure pathway to create a pathway specific hazard index (HI) for each exposure scenario. The more the HI exceeds one (1), the greater the concern that adverse health effects will occur. The hazard quotient is not a percentage $\alpha$ probability.

The maximum concentration value was used as the exposure point concentration. '

\section{Current Land Use}

Since there is no current activity at the GRS, the current land use scenario is not applicable.

\section{Future Land Use}

Under the future land use scenario, carcinogenic risks and non-carcinogenic hazards were calculated for exposure of the future on-unit resident (adult and child) to surface soils and air. The on-site resident scenario was used because it is more conservative than the industrial scenario.

The estimate of the total risk for carcinogens, for the future residential scenario, is $3.8 \times 1005$. The cancer risk for ingestion of soil at the Grace Road Site was $8.8 \times 10-6$. Estimated risk was $4.7 \times 10^{-8}$ for dermal contact with soils at the unit. The cancer risk for inhalation of particulate from soils at Grace Road is $2.9 \times 10^{-5}$, which is within the $1 \times 10^{-4}$ to $\mathrm{I} \times 10^{-6}$ range. Arsenic is the only contaminant responsible for the above risk estimates.

The non-carcinogenic hazard/risk (HI) for the soil pathways were calculated for adulthood and childhood exposures combined and for childhood exposure only. All of the exposure pathways for the on-unit resident have anon-carcinogenic hazard/risk of less than one. A summary of the risk presented by the chemical of concern, arsenic, is provided in Table 2. An analysis of data collected as a result of the studies performed at the Grace Road Site indicates that the GRS is not a risk to human health.

\section{Ecological Risks}

The ecological information base for Grace Road Site consists of a unit-specific threatened, endangered and sensitive species survey and a unit-specific ecological reconnaissance. Additional information is contained in the existing unit history, preliminary unit evaluation, and unit characterization data. These informational sounces form the basis for this characterization. This information can be summarized as follows

- There is no evidence of vegetation stress or ecological impact related to the unit;

- There are no threatened or endangered species known to exist at or in the vicinity of the unit;

- Review of the unit characterization data indicates that there are no constituents in the physical media analyzed at Grace Road which are significantly different from the unit specific background condition.

Based on the physical and analytical data obtained for this unit, there is no compelling evidence that waste materials were managed or disposed at Grace Road. Therefore, it is reasonable to conclude that the unit, as it is currently characterized, presents no significant ecological risk. 
Table 1. Comparison of unit specific soil concentration to two times background concentration and Risk-Based Concentrations (RBCs)

\begin{tabular}{|c|c|c|c|c|}
\hline Contaminant (units) & \begin{tabular}{|l} 
Maximum \\
Concentration \\
\end{tabular} & $\begin{array}{l}\text { Average Bat } \text { Soil } \\
\text { Concentration (GRS-10) } \\
\end{array}$ & $\begin{array}{l}\text { Two Times } \\
\text { Background }\end{array}$ & $\begin{array}{l}\text { RBC Value* } \\
\text {-(mg } / \mathrm{kg})\end{array}$ \\
\hline $\begin{array}{l}\text {-Bis(2-ethylhexyl)- } \\
\text { Phthalate (mg/kg) }\end{array}$ & 6.8 & 4.7 & 9.4 & $-\frac{104}{46}$ \\
\hline Carbon Disulfide (mg/kg) & $0.002 \mathrm{~J}$ & Not Detected & Not Detected $^{-}$ & 7800 \\
\hline DDT(mg/kg) & $0.0063 \mathrm{~J}$ & Not Detected & Not Detected & 19 \\
\hline styrene $(\mathrm{mg} / \mathrm{kg})$ & $0.004 \mathrm{~J}$ & Not Detected & Not Detected & 16000 \\
\hline Acetone $(\mathrm{mg} / \mathrm{kg})$ & $0.002 \mathrm{~J}$ & Not Detected & Not Detected & 7800 \\
\hline Toluene $(\mathrm{mg} / \mathrm{kg})$ & $0.003 \mathrm{~J}$ & Not Detected & Not Detected & 16000 \\
\hline Di-n-Butyl-Phthalate'(mg/kg) & $53 \mathrm{~J}$ & Not Detected & Not Detected & 7800 \\
\hline Trichloroethylene $(\mathrm{mg} / \mathrm{kg})^{-}$ & 0.004 & Not Detected & Not Detected & 58 \\
\hline Xylene' $(\mathrm{mg} / \mathrm{kg})$ & 0.007 & Not Detected & Not Detocted & 160000 \\
\hline Arsenic (mg/kg) & 3.2 & Not Detected & Not Detected & 037 \\
\hline Barium (mg/kg) & 48.4 & Not Detected & Not Detected & 5500 \\
\hline Cadmium (mg/kg) & 1.8 & Not Detected & Not Detected & 39 \\
\hline Chromium (VI) (mg/kg) & 29.6 & 4.2 & 8.4 & 390 \\
\hline Mercury (mg/kg) & 0.15 & Not Detected & Not Detected & 23 \\
\hline Lead $(\mathrm{mg} / \mathrm{kg})$ & 48.1 & 1.4 & 2.8 & $400 * *$ \\
\hline Selenium (mg/kg) & 1.3 & Not Detected & Not Detected & 390 \\
\hline $\operatorname{Tin}(\mathrm{mg} / \mathrm{kg})^{-}$ & 32.5 & Not Detected & Not Detected & 47000 \\
\hline Vanadium $(\mathrm{mg} / \mathrm{kg})$ & 61.8 & Not Detected & Not Detected & 550 \\
\hline Zinc (m\#kg) & 7.0 & Not Detected & Not Detected & 23000 \\
\hline
\end{tabular}

* EPA Region III, Risk-Based Concentration Table, January-June 1995, dated March 7, 1995

$\mathrm{J}=$ estimated value

** The screening level for lead in soil is $400 \mathrm{mg} / \mathrm{kg}$ for residential land use. This value is described in OSWER Directive 9355.4-12, Revised Internal Soil Lead Guidance for CERCLA Sites and RCRA Corrective Action Facilities, dated July 14, 1994 and issued by Elliott P. Lewis of the USEPA. The screening level for lead was calculated using the USEPA new integrated exposure uptake biokinetic model with default parameters.

Table 2. Carcinogenic/Non-Carcinogenic Results for $3.2 \mathrm{mg} / \mathrm{k}_{\mathrm{g}}$ Arsenic.

\begin{tabular}{|c|c|c|c|}
\hline \multirow[b]{2}{*}{ Pathway } & \multirow{2}{*}{$\begin{array}{l}\text { carcinogenic Risk } \\
\text { Adult and Child (Unitless) }\end{array}$} & \multicolumn{2}{|l|}{ Non-carcinogenic Risk } \\
\hline & & Adult and Child (Unitess) & $\begin{array}{l}\text { Child only } \\
\text { (Unitless) }\end{array}$ \\
\hline $\begin{array}{l}\text { Dermal Contact } \\
\text { ingestion } \\
\text { Inhalation }\end{array}$ & $\begin{array}{l}4.7 \times 10^{-08} \\
8.8 \times 10^{-06} \\
2.9 \times 10^{-05}\end{array}$ & $\begin{array}{l}\mathbf{0 . 0 0 0 3 9} \\
0.15 \\
0.055\end{array}$ & $\begin{array}{l}0.00026 \\
0.14 \\
0.047\end{array}$ \\
\hline Total Risk & $3.8 \times 10^{-05}$ & 0.2 & 019 \\
\hline
\end{tabular}




\section{SECTION IV.C SUMMARY OF THE CONSIDERED ALTERNATIVE}

EPA OSWER Directive 9355.0-30 (EPA, 1991a) states, "where the cumulative carcinogenic site risk to an individual based on reasonable maximum exposure for both current and future land use is less than $1 \times 10^{-}$ 04, and the non-carcinogenic hazand quotient is less than 1 , action is generally not warranted unless there are adverse environmental impacts." The remedial investigation for the Grace Road Site indicates that there is no impact to human health or the environment. Therefore, no action is needed at GRS and no other alternatives were considered

\section{Description of Preferred Alternative}

The No Action Alternative means that no remedial action will be performed at the Grace Road. No Five Year Review(s) will be conducted There is no waste to treat, no engineering controls required and there are no Applicable or Relevant and Appropriate Requirements (ARARs) or costs associated with this action. The alternative can be implemented immediately upon approval.

Although not necessary for this no action alternative, default institutional controls exist at SRS. Access to SRS is controlled by continuously manned barricades. The entire SRS facility is surrounded by an exclusion fence, except along the Savannah River. The Site is posted against trespassing under state and Federal statutes.

\section{SECTION IV.D. SUMMARY OF THE NO ACTION ALTERNATIVE}

According to EPA guidance document 9355.3-02 (EPA, 1989), if there is no current or potential threat to human health and the environment and no action is warranted, the CERCLA 121 requirements are not triggered. This means that there is no need to evaluate other alternatives or the no action alternative against the nine criteria specified under CERCLA.

Since the no action alternative is warranted, it satisfies the CERCLA criteria The no action alternative will be the final action for the Grace Road Site. This solution is meant to be permanent and effective in both the long and short term. No Five Year Review will be conducted The no action decision is the least cost option with no capital, operating, or monitoring cost and is protective of human health and the environment. Additionally, this plan provides for community involvement through a document review process and a public comment period. Public input will be documented in the ROD. 


\section{REFERENCES}

DOE (U.S. Department of Energy), 1994. Public Involvement, A Plan for the Savannah River Site. Savannah River Operations Office, Aiken, South Carolina.

EPA (U.S. Environmental Protection Agency), 1989 Guidance on Preparing Superfund Decision Documents Office of Solid Waste and Emergency Response - OSWER Directive 9355.3-02.

EPA (U.S. Environmental Protection Agency), 1991a. Role of Baseline Risk Assessment in Superfund Remedy Selection Decisions. Office of Solid Waste and Emergency Response - OSWER Directive 9355.0-30.

EPA (U.S. Environmental Protection Agency), 1994 Revised Internal Soil Lead Guidance for CERCLA Sites and RCRA Corrective Actions Office of Solid Waste and Emergency Response - OSWER Directive 9355.4-12.

EPA (U.S. Environmental Protection Agency), RiskBased Concentration Table, EPA-III, January-June 1995, dated March 7,1995

FFA, 1993. Federal Facility Agreement for the Savannah River Site, Administrative Docket Number 89-05-FF (effective date: August 16, 1993).

WSRC (Westinghouse Savannah River Company), RCRA Facility Investigation Remedial Investigation Plan for the Grace Road Site (U), WSRC-RP-90-1250, Rev.0, Westinghouse Savannah River Company, Aiken, SC, (1990).

WSRC (Westinghouse Savannah River Company), RFIIRI Report for Grace Road Site (631-22G) (U), WSRC-RP-95-93, Rev. 1.1, Westinghouse Savannah River Company, Aiken, SC. (includes baseline risk assessment) (1996) 


\section{GLOSSARY}

Administrative Record File: A file that is maintained and contains all information used to make a decision on the selection of response action under the Comprehensive Environmental Response, Compensation, and Liability Act. This file is to be available for public review, and a copy is to be established at or near the Site, usually at one of the information repositories. Also, a duplicate file is held in a central location, such as a regional or state office.

ARARs: Applicable or Relevant and Appropriate Requirements. Refers to the federal and state requirements that a selected remedy will attain. These requirements may vary from site to site.

Baseline Risk Assessment: An analysis of the potential adverse health effects (current or future) caused by hazardous substance release from a site in the absence of any actions to control or mitigate these releases.

Characterization: The compilation of all available data about waste units to determine the rate and extent of contaminant migration resulting from the waste site, and the concentration of any contaminants that maybe present.

Contamination: The deposition of unwanted chemical and/or radioactive material at a site.

Exposure: Contact of an organism with a chemical or physical agent. Exposure is quantified as the amount of the agent available at the exchange boundaries of the organism (e.g., skin, lungs, digestive tract) and available for absorption.

Federal Facility Agreement (FFA): A legally binding agreement between regulatory agencies (EPA and SCDHEC) and regulated entities (DOE) that sets standards and schedules for compliance with environmental laws.

Magnetometer. A device used to locate buried metallic objects which create a measurable disturbance in the magnetic field of the earth.

Media: A pathway through which contaminants are transferred. Five media by which contaminants maybe transferred are groundwater, soil, surface water, sediments, and air.

National Priorities List (NPL): Formal listing of the nation's worst contaminated sites, as established by the Comprehensive Environmental Response, Compensation, and Liability Act.
Operation and Maintenance (O\&M): Activities conducted at a site after a response action occurs to ensure that the cleanup and/or systems are functioning properly.

Parts per Billion: A unit of measure of concentration equivalent to the weight/volume or weight/mass ratio expressed as ug/L or $u g / k g$, respectively.

Parts per Million: A unit of measure of concentration equivalent to the weight/volume or weight/mass ratio expressed as $\mathrm{mg} / \mathrm{L}$ or $\mathrm{mg} / \mathrm{kg}$, respectively.

RCRA Part B Permit Application. The second part of the permit application that includes detailed and highly technical information concerning the treatment, storage and disposal (TSD) facility in question. There is no standard form for the Part B; instead the facility must submit information based on the regulatory requirements.

Reduction of Toxicity, Mobility, and Volume through Treatment. The assessment against this criterion evaluates the anticipated performance of the specific treatment technologies an alternative may employ.

Resource Conservation and Recovery Act (RCRA): Resource Conservation and Recovery Act of 1976. What is commonly referred to as RCRA is an amendment to the first pieces of federal solid waste legislation called the Solid Waste Disposal Act of 1\%5. RCRA was amended in 1980 and most recently on November 8, 1984 by the Hazardous and Solid Waste Amendments (HWSA).

Record of Decision (ROD): A legal document that describes the final remedial actions selected for a Superfund site, why the remedial actions were chosen and not others, how much they will cost, and how the public responded to the proposed remedial actions.

Responsiveness Summary: A summary of oral and/or written public comments received during the proposed plan comment period.

Superfund: The common name used for the Comprehensive Environmental Response, Compensation, and Liability Act. The Superfund program was established to help fund cleanup of hazardous waste sites. It also allows for legal action to force those responsible for the sites to clean them up. 